\title{
The Role of Radiography Guided Non-Palpable Breast Lesion Marking On the Diagnosis of Early Breast Cancer and Proliferative Diseases
}

\section{Nonpalpabl Meme Lezyonlarında Işaretlemenin Erken Evre Meme Kanseri ve Proliferatif Hastalıkları Tespit Etmedeki Rolü}

\author{
Bahattin Özlü ${ }^{1}$, Memduh Şahin ${ }^{2^{*}}, K_{ı}$ ıılcım Eren Erdoğan ${ }^{3}$, Belma Koçer ${ }^{4}$ \\ ${ }^{1}$ Mersin City Hospital Gastroenterological Surgery Department, Mersin \\ ${ }^{2}$ S işli Hamidiye Etfal Training and Research Hospital Gastroenterology Department, I stanbul \\ ${ }^{3}$ Cukurova University Patology Department, Adana \\ 4 Sakarya University Medical Faculty General Surgery Department, Sakarya
}

\begin{abstract}
Objective: The aim of this study was to determine the rate of proliferative and malignant breast lesions in patients who underwent excisional biopsy.

Materials and Methods: Non-palpable benign breast lesions in 112 female patients that were diagnosed by mammography and ultrasonography (USG) were analysed using the Breast Imaging Reporting and Data System (BIRADS) radiological classification system. Patients with a BI-RADS score of 3-5 for mammograms and breast mass excised later were compared according to radiological and pathologic findings.

Results: For non-palpable breast lesions, a BI-RADS type 4 radiological image was most frequently obtained $(62.5 \%, 70$ cases). Most lesions $(52.7 \%, \mathrm{n}=59)$ were benign, $36.6 \% \quad(n=41)$ were proliferative and $10.7 \%$ $(n=12)$ were malignant. The most frequently seen benign lesion was either a simple cystic disease or a proliferative disease that was classified with or without atypia. A few patients $(16.1 \%, \mathrm{n}=18)$ had proliferative lesions with atypical ductal hyperplasia and $20.5 \% \quad(n=23)$ of the patients had proliferative lesions without atypia; no significant difference in proliferative lesions was observed between these two groups $(p=.466)$. Six patients were diagnosed with invasive ductal carcinoma and six patients were diagnosed with ductal carcinoma in situ. In patients with atypical ductal hyperplasia, atypical columnar epithelial cell changes $(61.1 \%)$ were more common than without atypia $(43.5 \%)$, but these values were not significantly different.
\end{abstract}

Conclusion: The marking of non-palpable breast lesions followed by excisional biopsy is a valuable method for detecting and staging suspicious lesions. Additionally, the BI-RADS scoring system is a reliable method for ruling out malignancy in non-palpable breast lesions during follow-up.

Key Words: Breast, marking, biopsy, Non-palpable

\section{ÖZET}

Amaç: Çalışmamızda retrospektif olarak elde edilen tarama mamografisi ve ultrasonografi ile tespit edilen palpe edilemeyen meme kitleleri incelenmiş olup bu hastaların daha sonra eksizyonel biyopsi verileri değerlendirilmiştir. Çalışmamızda poliferatif ve malign meme lezyonlarının sıklığının radyolojik bulgulara ve patolojik sonuçlara göre incelenmesi amaçlanmıştır.

Yöntem ve Gereçler: Çalışmamızda Mamografi ve ultrasonografi ile tanı alan 112 kadin hasta "Meme görünteleme bildirimi ve data sistemi " (BI-RADS) ile klasifiye edilmiştir. BI-RADS 3-5 skoru alan hastaların kitleleri daha sonra eksize edilmiş olup radyolojik ve patolojik sonuçlar çalışmamızda karşılaştırılmıştır.

Bulgular: Palpe edilemeyen meme lezyonlarında en s1k BI-RADS tip 4 gözlenmiştir (70 vaka, \%62.5). En s1k benign lezyonlar ( $\% 52.7 \mathrm{n}=59)$ gözlenmiş olup bu lezyonlar1 proliferative (n: $41 \% 36.3$ ) ve malign ( $\mathrm{n}$ : 12,\%10.7) olgular takip etmiştir. En sık izlenen benign olgular basit kistik hastalık olup proliferatif lezyonlar atipili ve atipisiz olarak sınıflandırılmıştır. Hastaların az k1smında \%16.1\% ( $n=18)$ atipik duktal hiperplazi ile proliferatif lezonlar izlenirken $23(\% 20.5)$ hastada atipisiz proliferatif lezyonlar izlenmiştir. Her iki grup arasında proliferatif lezyon bakımından belirli bir farklılık gözlenmemiştir $(p=0.466)$. 6 hasta invasiv duktal karsinoma tanısı alırken 6 hasta invaziv duktal karsinoma in situ tanısı almıştır. Atipili proliferatif lezyonlarda kolumnar değişiklikler (\%61.1) atipisiz lezyonlara (\%43.5) göre daha s1k gözlenmesine rağmen aradaki fark istatistiksel olarak anlamlı bulunmamıştır.

Sonuç: Ultrasonografi ile yapılan tarama mamografileri sonucu gerçekleşen eksizyonel biyopsi malign riski taşıan meme lezyonları ve erken meme kanserinin derecelendirilmesi ve tanısı için değerli yöntemlerdir. Ek olarak BI-RADS sistemi palpe edilemeyen meme lezyonlarında takip sırasında malignansiyi dışlamak açısından değerli bir diagnostik metottur.

Anahtar Kelimeler: Meme, işaretleme, biyopsi, nonpalpable

*Sorumlu Yazar: Dr. Memduh ŞAHİN, Sağlık Bilimleri Üniversitesi Şişli Hamidiye Etfal Eğitim ve Araştırma Hastanesi Halaskargazi Cad. Etfal Sk. 34371 Șișli / İstanbul, Tel: +90 (505) 61720 87, Faks : +90 (212) 22407 72, E-mail: memsahinsahin@hotmail.com 


\section{Introduction}

Breast cancer is the most common cancer among women in Turkey and the United States (U.S.) $(1,2)$. In the U.S., breast cancer is detected in one in every eight women, and $15 \%-20 \%$ of all cancer deaths are the result of a breast malignancy (1). Tumours discovered during routine screening tend to be slow-growing, and it is thought that their late diagnosis does not substantially alter the prognosis. This is because the cell doubling time of breast cancers can range from less than 50 days to longer than 500 days, which implies that the tumours that are supposed to have been diagnosed 'early' have actually been growing for an average of 6-10 years (3).

However, some benign breast disorders are important risk factors for later bilateral breast cancer development (4), and these benign lesions are grouped into three risk categories: nonproliferative lesions, proliferative lesions without atypia and proliferative lesions with atypia (5).

Columnar cells of the breast denote a morphological spectrum comprising simple columnar cell change, columnar cell lesions, columnar cell hyperplasia and atypical columnar cell hyperplasia. Columnar cell lesions with atypia have been described by a variety of names in existing literature, and the Pathology and Genetics research group of the World Health Organisation has renamed lesions containing atypia as flat epithelial atypia (6). Although atypical hyperplasia is 2-3 times more frequent in columnar cell lesions, the presence of such lesions does not increase the risk of atypical hyperplasia and the cancer risk is equal among the columnar cell lesion subgroups (7).

For consistency in terminology and to standardise the reporting of results of mammographic exams, the American College of Radiology has developed a system called the Breast Imaging Reporting and Data System (BI-RADS) as a systematic review of mammography (8).

As non-invasive methods cannot adequately distinguish between benign and malignant breast lesions, these findings need to be biopsied, and biopsy localisation techniques have been developed to accurately diagnose non-palpable breast lesions.

We retrospectively screened suspicious nonpalpable breast masses that were detected during routine mammographic or sonographic methods and later wire marked them for an excisional biopsy. The aim of the study was to determine the rate of proliferative and malignant breast lesions in patients who underwent wire-guided excisional biopsy.

\section{Materials and Methods}

This retrospective analysis was performed at Ankara Numune Training and Research Hospital on 112 female patients between August 2005 and November 2008. Patients with a BI-RADS score of 3-5 for mammograms and breast mass excised later were compared according to radiological and pathologic findings. Patients with a history of palpable breast mass were excluded. All the biopsy samples were collected using the wire-guided excisional method. BI-RADS was used for the radiologic classification of the lesion subtypes. Stereotactic-guided mammography, which supports the use of a 20-gauge Kopansky wire, was used for marking the abnormalities. Of 112 suspicious lesions, 26 were wire marked with mammograms, and the remainder were marked using ultrasonography (USG) methods. Solitary and dense lesions were marked with USG, while deep breast lesions were marked with mammography. Following the marking stage, the excisional biopsy was performed in the surgical unit under general anaesthesia. The marked fields were removed with a margin of at least 1 centimetre of intact surrounding tissue, and adequate removal was ensured using specimen radiography imaging after the biopsy. (Specimen radiography was performed for both mammography and USG detected breast masses.) Data on age, lesion location, mammogram and USG views, histopathological diagnosis and the medical history for all patients were collected from the hospital database. In cases of malignant lesions, surgical margin positivity and the need for re-excision were also recorded, and complications arising during the marking and subsequent surgery were obtained.

Statistical Analysis: Data were analysed by analysis of variance (ANOVA) using Statistical Package for the Social Sciences (SPSS, version 11.0). Homogeneity of distribution was quantified using indices derived from the skewness and kurtosis score (between +2 and-2). One-way ANOVA was used to determine whether any significant differences existed between three or more independent groups (BI-RADS 3-4-5). Data were considered statistically significant if $p \leq 0.05$. 


\section{Results}

The mean age of the patients was 49.5 years (range 24-81 y). The mean age of patients with benign lesions was 49.3 years, whereas the average age of patients with proliferative and malignant lesions was 49.2 and 51.6 years, respectively. The most wire markings $(\mathrm{n}=55 ; 49.1 \%)$ were performed in the non-palpable solid mass group(s). Other markings were used for microcalcification $\quad(\mathrm{n}=48, \quad 42.9 \%)$, microcalcification and non-palpable mass $(n=5$, $4.5 \%)$ and palpable suspicious mass $(n=3,2.7 \%)$. The BI-RADS 4 stage $(n=70,62.5 \%)$ was most predominant, followed by stages BI-RADS 3 $(\mathrm{n}=40,35.7 \%)$ and BI-RADS $5(\mathrm{n}=2,1.8 \%)$. Mammography was used for the wire marking procedure in $23.2 \% \quad(\mathrm{n}=26)$ of the patients, and USG was used in the other $76.8 \%(n=86)$. The average diameter of the breast lesion was $0.9 \mathrm{~cm}$ (between 0.3 and $1.6 \mathrm{~cm}$ ). Of the markings, $55.4 \%$ were performed on the left breast and $44.6 \%$ on the right. The majority of the lesions were located on the upper outer side of the breast (67.9\%), followed by the lower outer side $(18.8 \%)$, the upper inner side $(12.5 \%)$ and the lower inner side $(0.9 \%)$. Table 1 shows some of the patients' characteristics. All surgical procedures were performed under general anaesthesia. Picture 1 shows a representative mammogram of a marking procedure, and Picture 2 shows a specimen radiography image.

Based on sample pathology, the patients were grouped as having benign, proliferative or malignant lesions. Of the samples, $52.7 \%(\mathrm{n}=59)$ were benign lesions, $36.6 \% \quad(n=41)$ were proliferative and $10.7 \%(\mathrm{n}=12)$ were malignant. Table 2 presents the pathology results according to the BI-RADS classification.

Table 1. Some characteristics of the patients with non-palpable breast lesions (Lesion localization, marking procedure,BI-RADS score) marking procedure, age, BI-RADS score)

\begin{tabular}{lll}
\hline Lesion localisation & Marking procedure & BI-RADS SCORE \\
\hline upper outer side of the breast $(\mathrm{n}: 76,67.9 \%)$ & - Mammography: & BI-RADS 3 \\
& $23.2 \%(\mathrm{n}=26)$ & $(\mathrm{n}=40,35.7 \%)$ \\
\hline lower outer side (n:21, 18.8\%), & -USG: 76.8\% $(\mathrm{n}=86)$ & $\begin{array}{l}\text { BI-RADS } 4 \\
(\mathrm{n}=70,62.5 \%)\end{array}$ \\
\hline upper inner side (n:14, 12.5\%) & & BI-RADS 5 \\
& & $(\mathrm{n}=2,1.8 \%)$. \\
\hline
\end{tabular}

lower inner side (n: $1,0.9 \%$ ).

$\mathrm{n}$ : Number

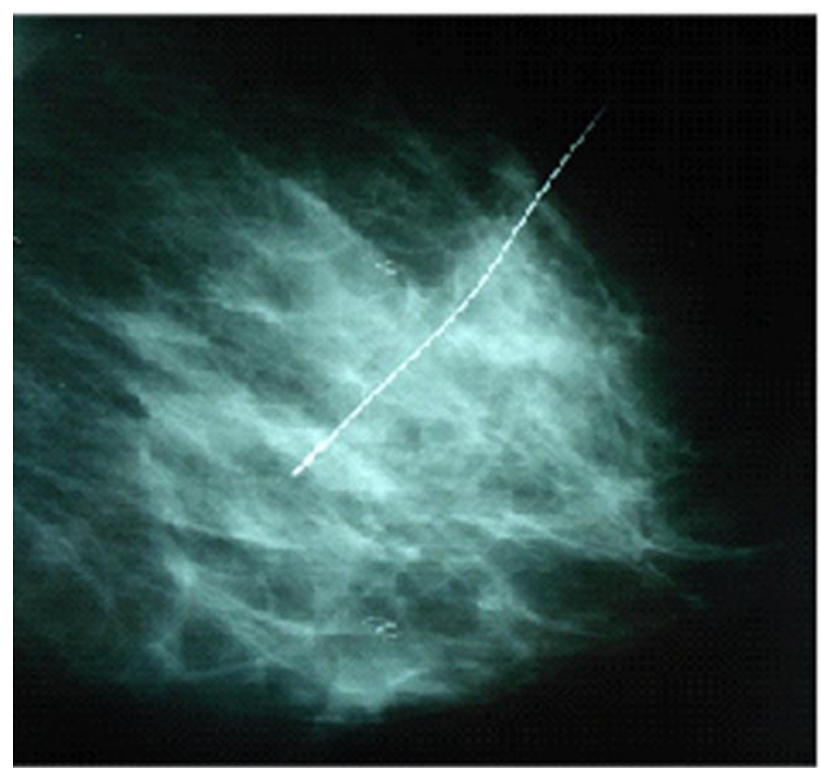

Picture 1. Mammogram after wire marking.

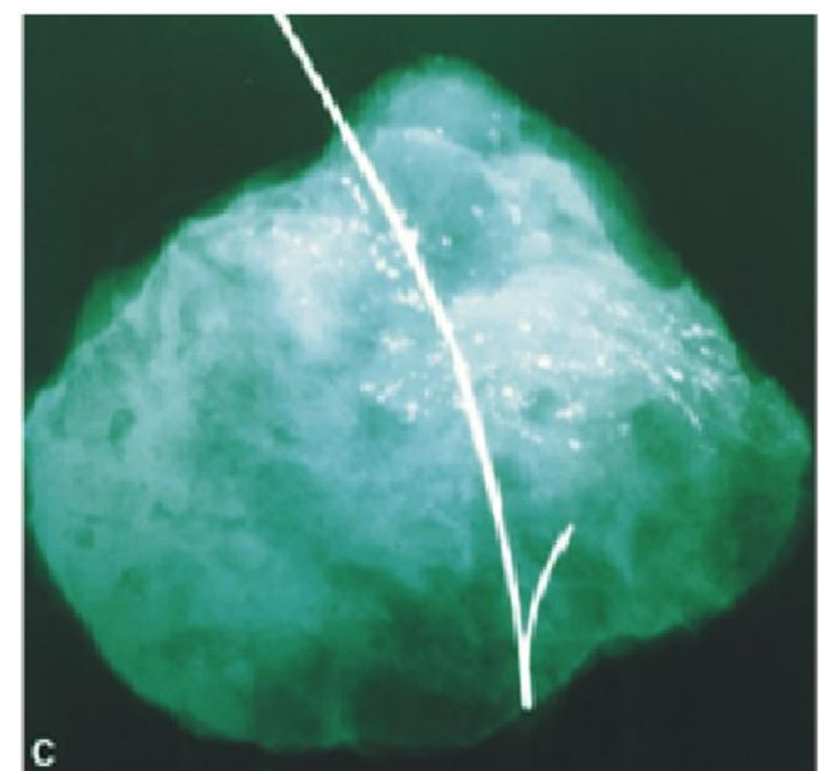

Picture 2. Specimen radyography after excisional biopsy. 
Özlü et al. / Breast Lesion Marking and Non-Palpable Breast Lesions

Table 2. Patients pathology according to BI-RADS score

\begin{tabular}{|c|c|c|c|c|c|c|c|c|c|c|}
\hline & & & $\begin{array}{c}\text { Fibro } \\
\text { adenoma }\end{array}$ & $\begin{array}{c}\text { Fibrocystic } \\
\text { Disease }\end{array}$ & $\begin{array}{c}\text { Fat } \\
\text { Necrosis }\end{array}$ & $\begin{array}{c}\text { Proliferation }+ \\
\text { Atypia }\end{array}$ & $\begin{array}{c}\text { Proliferation } \\
\text { without } \\
\text { Atypia }\end{array}$ & DCIS & $\begin{array}{c}\text { Invasive } \\
\text { Carcinoma }\end{array}$ & Total \\
\hline \multirow{6}{*}{$\begin{array}{l}\text { B } \\
\text { I } \\
\text { R } \\
\text { A } \\
\text { D } \\
\text { S }\end{array}$} & \multirow[b]{2}{*}{3} & number & 2 & 26 & 0 & 5 & 5 & 2 & 0 & 40 \\
\hline & & $\begin{array}{l}\text { BI- } \\
\text { RADS\% }\end{array}$ & $5.0 \%$ & $6.0 \%$ & $0 \%$ & $12.5 \%$ & $12.5 \%$ & $5 \%$ & $0 \%$ & $100.0 \%$ \\
\hline & \multirow[b]{2}{*}{4} & number & 6 & 22 & 2 & 13 & 17 & 4 & 6 & 70 \\
\hline & & $\begin{array}{l}\text { BI- } \\
\text { RADS\% }\end{array}$ & $8.6 \%$ & $31.4 \%$ & $2.9 \%$ & $18.6 \%$ & $24.3 \%$ & $5.7 \%$ & $8.6 \%$ & $100.0 \%$ \\
\hline & \multirow[b]{2}{*}{5} & number & 0 & 0 & 1 & 0 & 1 & 0 & 0 & 2 \\
\hline & & $\begin{array}{l}\text { BI- } \\
\text { RADS\% }\end{array}$ & $0 \%$ & $0 \%$ & $50.0 \%$ & $0 \%$ & $50.0 \%$ & $0 \%$ & $0 \%$ & $100.0 \%$ \\
\hline \multirow{2}{*}{\multicolumn{2}{|c|}{ TOTAL }} & Number & 8 & 48 & 3 & 18 & 23 & 6 & 6 & 112 \\
\hline & & Total $\%$ & $7.1 \%$ & $42.9 \%$ & $2.7 \%$ & $16.1 \%$ & $20.5 \%$ & $5.4 \%$ & $5.4 \%$ & $100.0 \%$ \\
\hline
\end{tabular}

Abbreviations: DCIS: Ductal Carcinoma in Situ

Table 3. BI-RADS score between atypia and without atypia subgroups.

\begin{tabular}{|c|c|c|c|c|c|c|}
\hline & & & & BI-RADS & & \\
\hline & & & BI-RADS3 & BI-RADS4 & BI-RADS5 & 1U1AL \\
\hline & & Number (n) & 5 & 17 & 1 & 23 \\
\hline ATYPICAL & $\mathrm{NO}$ & Percent & $21.7 \%$ & $73.9 \%$ & $4.3 \%$ & $100.0 \%$ \\
\hline HYPERPLASIA & $\mathrm{YES}$ & Number (n) & 4 & 14 & & 18 \\
\hline & 1LS & Percent & $22.2 \%$ & $77.8 \%$ & & $100.0 \%$ \\
\hline TOTAI & & Number (n) & 9 & 31 & 1 & 41 \\
\hline HOAL & & Percent & $22.0 \%$ & $75.6 \%$ & $2.4 \%$ & $100.0 \%$ \\
\hline
\end{tabular}

n: NUMBER

The suspected lesion was removed surgically from all patients via a mammogram guided procedure. In one patient $(0.9 \%)$, the wire was cut during the surgery. Most of the benign lesions $(81.3 \%)$ were found to be a simple cystic disorder, $13.6 \%$ were fibroadenomas and $5.1 \%$ were fat necrosis.

Proliferative lesions were further classified by the presence of atypia, and these two groups were further divided into three subgroups: sclerosing adenosis, papillomatosis and ductal epithelial hyperplasia. Of the patients, $16.1 \%(n=18)$ had proliferative lesions with atypical ductal hyperplasia and $20.5 \% \quad(n=23)$ had proliferative lesions without atypia. Table 3 presents the distribution of the proliferative lesions according to the BI-RADS classification. No significant difference was found in the BI-RADS scores between the groups with and without atypia $(p=.669)$.

In the proliferative group, 13 patients $(31.7 \%)$ had sclerosing adenosis and 19 patients (46.3\%) showed papillomatous changes (Picture 3). These lesions were generally found to occur with ductal epithelial hyperplasia, and only three (7.3\%) patients had ductal epithelial hyperplasia without proliferative changes. Among the patients, 44.4\% with atypical ductal hyperplasia and $21.7 \%$ with proliferative lesions also had sclerosing adenosis.

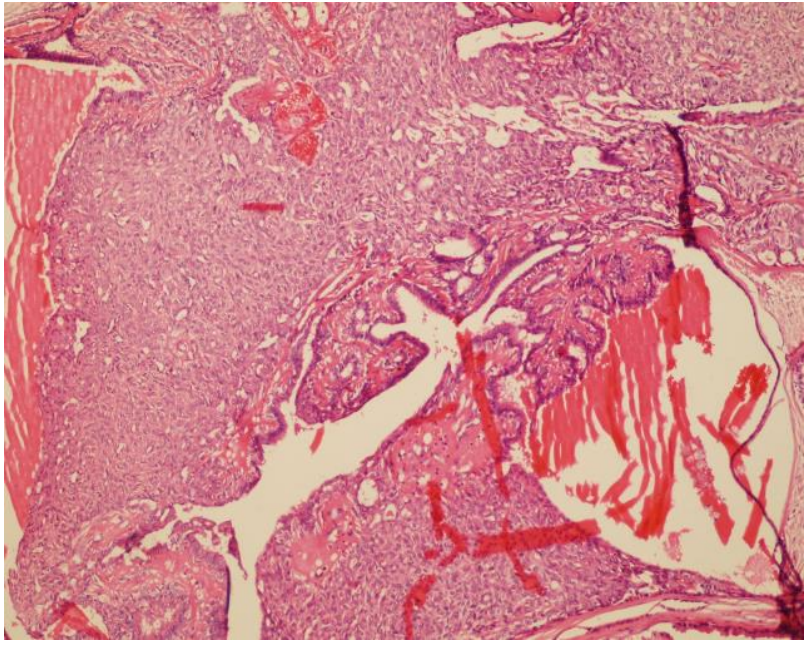

Picture 3. Intraductal papillomatosis in the breast tissue. 
Papillomatous changes were found in $50 \%$ of the patients with atypical ductal hyperplasia and in $43.7 \%$ of the patients with proliferative lesions without atypia. Sclerosing adenosis and papillomatous changes occurred more frequently in lesions with atypical proliferation. However, these changes were not statistically significant $(p=.121$ for sclerosing adenosis, $p=.678$ for papillomatosis).

Proliferative lesions were also examined for columnar changes (atypical changes, without atypia or no change) as shown in Picture 4. Columnar cell changes were accompanied by other pathologies, and the distribution of these lesions is given in Table 4. In patients with atypical ductal hyperplasia, atypical columnar epithelial cell changes were more common $(61.1 \%)$ than ductal epithelial hyperplasia without atypia (43.5\%), but these values were not statistically significant $(p=.466)$.

After an excisional biopsy, pathologic investigation showed atypical ductal epithelial hyperplasia in 18 of the 41 proliferative lesions; and one biopsy, after wire marking, showed columnar cell changes without atypia apart from atypical ductal hyperplasia. The excisional biopsies from 12 patients were found to be malignant. Table 5 shows the BI-RADS distribution of patients who obtained a score indicating malignancy.
Of the 12 patients diagnosed with invasive ductal carcinoma (malignant lesions), the postoperative pathologic stage in six patients was T1N0M0 (stage 1), while six patients were found to have ductal carcinoma in situ (DCIS). In all patients, the tumour diameter was less than $10 \mathrm{~mm}$, and three patients had clear surgical margins. One patient had a positive resection margin, one patient's tumour had a surgical margin of $1 \mathrm{~mm}$ and another patient had a $2-\mathrm{mm}$ surgical margin.

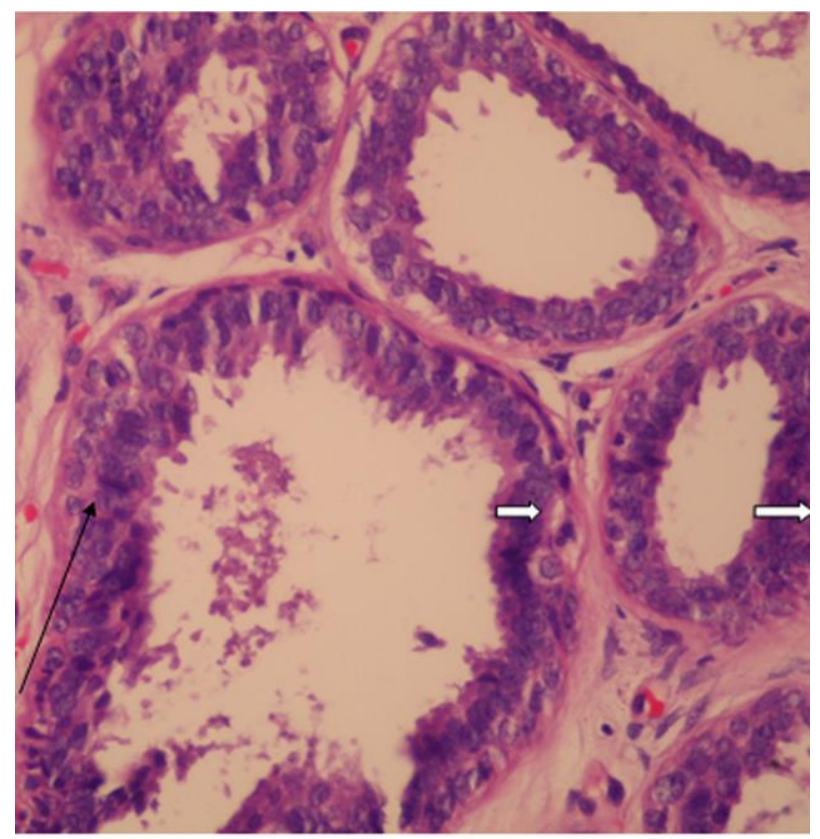

Picture 4. Columnar changes in the breast biopsy.

Table 4. Columnar cell changes in ductal hyperplasia

\begin{tabular}{|c|c|c|c|c|c|c|}
\hline & & & \multicolumn{3}{|c|}{ Columnar cell changes } & \multirow[b]{2}{*}{ Total } \\
\hline & & & No & Atypia & No Atypia & \\
\hline \multirow{4}{*}{$\begin{array}{l}\text { Atypical Ductal } \\
\text { Hyperplasia }\end{array}$} & \multirow{2}{*}{ No } & Number & 4 & 9 & 10 & 23 \\
\hline & & Percent & $17.4 \%$ & $39.1 \%$ & $43.5 \%$ & $100 \%$ \\
\hline & \multirow{2}{*}{ Yes } & Number & 3 & 4 & 11 & 18 \\
\hline & & Percent & $16.7 \%$ & $22.2 \%$ & $61.1 \%$ & $100 \%$ \\
\hline \multirow{2}{*}{ Total } & & Number & 7 & 13 & 21 & 41 \\
\hline & & Percent & $17.1 \%$ & $31.7 \%$ & $51.2 \%$ & $100.0 \%$ \\
\hline
\end{tabular}

Table 5. BI-RADS scores of malign patients

\begin{tabular}{lllccc}
\hline & & & BIRADS 3 & BIRADS 4 & Total \\
\hline \multirow{3}{*}{ MALIGN } & $\begin{array}{l}\text { İnvasive } \\
\text { carsinoma }\end{array}$ & Number (n) & & 6 & 6 \\
\cline { 2 - 5 } & Puctal Carcinoma & Percent & & $50,0 \%$ & $50,0 \%$ \\
\cline { 2 - 5 } & Number (n) & 2 & 4 & 6 \\
\cline { 2 - 5 } Total & Percent & $16,7 \%$ & $33,3 \%$ & $50,0 \%$ \\
\hline & & Number (n) & 2 & 10 & 12 \\
\cline { 3 - 5 } & & Percent & $16,7 \%$ & $83,3 \%$ & $100,0 \%$ \\
\hline
\end{tabular}


Pathology showed that four patients had grade 4 DCIS without necrosis and the other two biopsy specimens showed necrosis with grade II DCIS. According to the Van Nuys Prognostic Index, one patient had a score of 1 and three patients had a score of 3 , which could be translated as low grade or low risk. Two patients had a high risk score (grade 5), and all patients tested positive for the hormone receptor.

Modified radical mastectomies were performed in three patients with intact surgical margins. Three patients' tumours were $1 \mathrm{~cm}$ away from the surgical border. These patients underwent subcutaneous mastectomy and axillary dissection. Figure 1 shows the surgical and medical therapies for DCIS patients.

\section{Discussion}

In women, excluding in situ lesions and nonmelanoma skin cancers, breast cancer accounts for
$26 \%$ of all cancers and $18 \%$ of all cancer-related deaths (9). If breast cancer is diagnosed at an early stage, proper treatment can reduce the mortality rate. While the five-year survival rate of stage I breast cancer is as high as $85 \%$, it falls to $30 \%$ for stage $3 \mathrm{~b}$ cancers (10). Mammography is an important tool for diagnosing non-palpable breast lesions because it has a sensitivity of detection between $85 \%$ and $95 \%$ (11). Thus, biopsies obtained during screening by mammography and USG are essential for identifying clinically nondetectable suspicious lesions, and specific marking methods have been developed for this purpose. In suspicious lesions such as microcalcifications and in asymmetric structures such as parenchymal distortions, diagnostic interventions are performed using mammography guided marking biopsy methods (12).

The most common radiomorphologic criteria necessitating a diagnostic biopsy are microcalcifications (13). In our study, lesions were

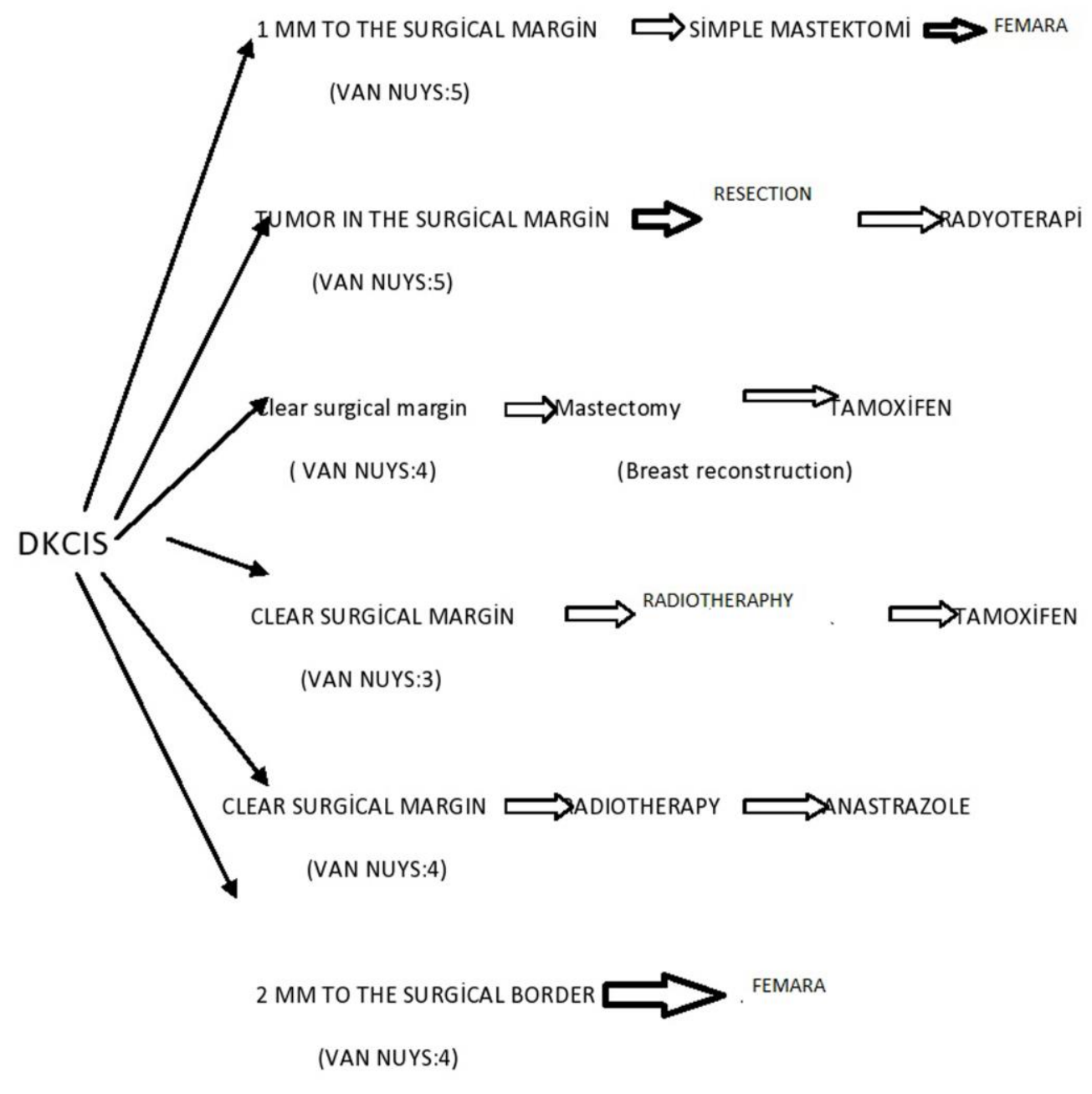

Fig. 1. Surgical and medical treatments of Ductal carcinoma in situ (DCIS) patients 
wire marked mostly because of the presence of non-palpable masses (49.1\%) or microcalcifications $(42.9 \%)$, and because of the presence of microcalcification in non-palpable masses $(4.5 \%)$ and solitary palpable masses $(2.7 \%)$.

One of the most important complications of the marking process is the inadequate removal of the lesion and the reported rates in different series range between $0 \%$ and $17 \%$ (14). We show a rate of $0 \%$. The frequency of positive breast cancer detection in patients who have undergone marking biopsy is reported to be between $10 \%$ and $36 \%$ (15).

In our study, pathological evaluation of the biopsied lesions that were non-palpable but showed a radiographic malignancy risk had a malignancy detection rate of $10.7 \%$. Less than $2 \%$ of the BI-RADS 3 lesions were found to be malignant. In one study, only $0.7 \%$ of the lesions initially scored as likely to be benign during mammography were later diagnosed as malignant. Orel et al. (15) found that only $2 \%$ of the BIRADS 3 lesions showed malignant changes upon further investigation, while found that $5 \%$ of the BI-RADS 3 lesions were malignant. This could be because, in our clinic, biopsy is not the initial option for BI-RADS 3 lesions and the standard approach in such patients is continuous follow-up during the next 6-12 months. If and when a change occurs in the nature or size of these lesions, a biopsy and further investigations are recommended. The malignancy rate shown here could also be higher than previous reports because criteria such as a family history of breast cancer, cancer diagnosis on the other breast and high grade dysplasia on previous biopsies were used to identify patients who needed rapid excision of the lesion rather than follow-up. As BI-RADS 4 lesions develop into malignancies in 10\%-20\% cases (16), a BI-RADS 4 lesion is a powerful indicator for a biopsy (16). The rate of malignancy detection in patients with a BI-RADS 4 lesion was $14.3 \%$ in our study. The average malignancy risk in BI-RADS 5 lesions is $80 \%$ and is also, therefore, a strong indicator for a biopsy. Liberman et al. (17) showed that $81 \%$ of all BIRADS 5 lesions were malignant (17). However, in our study, two patients had BI-RADS 5 lesions and pathology which showed that both were benign; one was fat necrosis and the other was hyperplasia without atypia. Fat necrosis can be confused with malignancy on a mammogram because of the dense mass of the lesion and the distortion of breast architecture (18).
According to the American College of Pathology, nonproliferative lesions carry a negligible risk of cancer development. A 1.5 - to 2 -fold greater risk of malignancy exists in proliferative lesions without atypia, while proliferative lesions with atypia have a 5-10-fold greater risk of malignancy (19). In our study, pathology showed that $12.5 \%$ of the patients with BI-RADS 3 and $18.6 \%$ of patients with BI-RADS 4 lesions had proliferative lesions with atypia.

Various studies have claimed that wire marking of lesions in patients undergoing subsequent excisional biopsy has an in situ cancer detection rate of $18 \%$ to $34 \%(19,20)$. However, the in situ cancer detection rate was $5.4 \%$ in our study.

Yao et al. (21) performed breast biopsies on patients with BI-RADS 2 and BI-RADS 3 lesions using a vacuum-assisted core device. Their predominant histopathological diagnoses were fibroadenoma (58\%) followed by fibrocystic mastopathy (32\%). Additionally, atypical ductal hyperplasia was found in only $0.3 \%$ of the patients and invasive breast cancer in only $0.2 \%$. Our study included 40 patients with a BI-RADS 3 score, and fibrocystic disease was the most prevalent benign diagnosis $(65 \%$ with proliferative lesions with atypia and $12.5 \%$ without atypia). A fibroadenoma was diagnosed in only two patients with a BIRADS 3 score. This difference in the fibroadenoma diagnosis could be due to the use of a wire-guided surgical excisional biopsy and increased material size. We believe that the surgical excision of a suspected lesion is the best way to correctly stage and diagnose the lesion, and this notion is supported by the high rate of ductal hyperplasia found in subjects with a BI-RADS 3 score (21).

In a study of 113 patients with atypical ductal hyperplasia, $93 \%$ of the lesions were category 4 BI-RADS lesions (22). Our study included 70 patients with BI-RADS 4 category lesions, and 17 $(24.3 \%)$ of these patients were diagnosed with proliferative lesions without atypia, whereas 13 subjects $(18.6 \%)$ had atypia with proliferation. A different histopathological classification, atypical ductal hyperplasia, was found in 14 patients $(77.8 \%)$ within the BI-RADS 4 subgroup. No statistically significant differences were found between the patients with or without atypia in the BI-RADS classification $(p=.669)$. Our patient group mainly included those with non-palpable breast lesions, which led to a low number of patients with BI-RADS 5 lesions. Additionally, the low number of patients with atypical ductal 
hyperplasia could be because of the relatively high rate of 'early biopsies' in these subjects.

Demiral et al. (23) conducted a study with 83 patients with non-palpable breast lesions. Of the 49 patients with BI-RADS 4 lesions, 14 were diagnosed as malignant using the hook-assisted biopsy method. They also proved the sensitivity and specificity of the mammography and USG using the hook-assisted breast biopsy results. In our study, 10 of the patients with a BI-RADS 4 score were later diagnosed with breast carcinoma (six with invasive carcinoma and four with ductal carcinoma). Similar to Demiral et al.'s study, our most malignant patients were in the BI-RADS 4 group. As a retrospective collection of patient follow-up data could not be compiled in this data analysis study, our aim was to investigate the BIRADS scores and examine the relationship between the histopathological results of a wide population diagnosed with non-palpable breast lesions.

Flat epithelial atypia was reported in $145(3.7 \%)$ of 3,948 breast biopsies and $1.5 \%$ of the patients also had atypical ductal hyperplasia. A statistically significant risk of malignancy and in situ carcinoma in the concomitant biopsy and during follow-up were also found (24). As our study is a retrospective analysis of the data available in the biopsy database, it was possible to contact all patients with lesions that carried a high risk of developing cancer.

In conclusion, mammography and/or ultrasonography with wire marking of nonpalpable breast lesions followed by excisional biopsy is a valuable method for the detection and staging of suspicious lesions and early breast cancer detection. Additionally, the BI-RADS scoring system is a reliable method for ruling out malignancy in non-palpable breast lesions during follow-up.

\section{Conflict of interest: None}

\section{References}

1. Jemal A, Bray F, Center MM, Ferlay J, Ward E, Forman D: Global cancer statistics. CA Cancer J Clin 2011; 61(2):69-90.

2. Turkish Ministry of Health, Turkish Public Health Institution:Turkey Cancer Control Programme. Breast Cancer Screening. Ankara, 2016.p:41.

3. Skrabonek P. False premises and false promises of breast cancer screening (review). Lancet 1985; 2(8450):316-320.
4. Connolly JL, Schnitt SJ. Benign breast disease: resolved and unresolved issues. Cancer 1993; 71(4): 1187-1189.

5. Worsham MJ, Raju U, Lu M, Kapke A, Cheng J, Wolman SR. Multiplicity of benignbreastlesions is a risk factor for progression to breast cancer. Clin Cancer Res 2007; 13 (18 Pt 1): 5474-5479.

6. Schnitt SJ. The diagnosis and management of preinvasive breast disease: flat epithelial atypia-classification, pathologic features and clinical significance. Breast Cancer Res 2003; 5(5):263-268.

7. Boulos F, Dupond W, Simpson J, Schuyler P, Sanders M, Freudenthal M, et al. Histologic Associations and Long-Term Canser Risk in Columnar Cell Lesions of the Breast. Cancer 2008;113(9): 2415-2421.

8. Damases CN, Brennan PC, Mello-Thoms C, McEntee MF. Mammographic Breast Density Assessment Using Automated Volumetric Software and Breast Imaging Reporting and Data System (BIRADS) Categorization by Expert Radiologists.Acad Radiol 2016; 23(1): 70-77.

9. Silverberg E, Lubera J. Cancer statistics, 1987. CA Cancer J Clin 1987; 37(1): 2-19.

10. Way LW, Doherty GM, Giuliano AE. Breast.Prognosis in carcinoma of the female breast. In: Way LW (eds). Current Surgical Diagnosis and Treatment. 11thed. Lange Medical Books.; 2003. p.319-344.

11. Balc1 P, Güneş N, Koçdor MA, Erkan N, Seçil M, Dicle O. Nonpalpabl kitle lezyonlarında preoperative lokalizasyon sonuçları: lezyonların mamografik analizi. Meme Hastalıkları Dergisi 1997; 4: 123-127.

12. Özdemir A. Preoperatif işaretleme yapılan nonpalpabl 381 meme lezyonunun değerlendirilmesi. Tanısal ve Girişimsel Radyoloji 2000; 6: 314-322.

13. Hasselgren PO, Hummel RP, Fieler MA. Breast biopsy with needle localization: influence of age and mammographic feature on the rate of malignancy in 350 non palpable breast lesions. Surgery 1991; 110: 623-628.

14. Bronstein AD, Kilcoyne RF, Moe RE. Complications of needle localization of foreign bodies and nonpalpable breast lesions. Arch Surg 1988; 123(6): 775-779.

15. Orel SG, Kay N, Reynolds C, Sullivan DC. BI-RADS categorization as a predictor of malignancy. Radiology 1999; 211(3): 845-850.

16. Obenauer S, Hermann KP, Grabbe E. Applications and literature review of the BI-RADS classification. Eur Radiol 2005; 15(5): 1027-1036.

17. Liberman L, Abramson AF, Squires FB, Glassman JR, Morris EA, Dershaw DD. The breast imaging reporting and data system: positive predictive value of mammographic features and final assessment categories. AJR Am J Roentgenol 1998; 171(1): 3540. 
18. Frates MC, Homer MJ, Robert NJ, Smith TJ. Noniatrogenic breast trauma. Breast Dis 1992; 5: 1119.

19. Fitzgibbons PL, Henson DE, Hutter RV. Benign breast changes and the risk for subsequent breast cancer: an update of the 1985 consensus statement. Cancer Committee of the College of American Pathologists. Arch Pathol Lab Med 1998; 122(12): 1053-1055.

20. Bilgen IG, Memiş A, Üstün EE. İşaretleme biyopsisi ile değerlendirilen 550 nonpalpabl meme lezyonunun retrospektif analizi.Türk Tanısal ve Girişimsel Radyoloji Dergisi 2002; 8: 487-495.

21. Yao F, Li J, Wan Y, Zhong Y, Wei W, Tu Y, et al. Sonographically guided vacuum-assisted breast biopsy for complete excision of presumed benign breast lesions.J Ultrasound Med 2012; 12: 1951 1957.

22. McGhan LJ, Pockaj BA, Wasif N, Giurescu ME, McCullough AE, Gray RJ. Atypical ductal hyperplasia on core biopsy: an automatic trigger for excisional biopsy?. Ann Surg Oncol 2012; 19(10): 3264-3269.

23. Demiral G, Senol M, Bayraktar B, Ozturk H, Celik Y, Boluk S. Diagnostic Value of Hook Wire Localization Technique for Non-Palpable Breast Lesions. J Clin Med Res 2016; 8(5): 389-395.

24. Uzoaru I, Morgan BR, Liu ZG, Bellafiore FJ, Gaudier FS, Lo JV, et al. Flat epithelial atypia with and without atypical ductal hyperplasia: to re-excise or not. Results of a 5-year prospective study. Virchows Arch 2012; 461(4): 419-423. 